\title{
PENDIDIKAN KARAKTER RELIGIUS, DISIPLIN DAN BAKAT MELALUI PENIGKATKAN KUALITAS SARANA PRASARANA SEKOLAH
}

\author{
${ }^{1}$ Andri Kautsar dan ${ }^{2}$ Johan Edi \\ Guru SDN 5 Air Kumbang \\ e-mail: andri.kautsar11@gmail.com
}

\begin{abstract}
This research focused on the character education program, and its function in instilling character education through Infrastructure. This research was qualitative. Data collection techniques used in this research were observation, in-depth interviews, documentation studies and literature studies. The results revealed that the change happened after the implementation of Infrastructure related to shaping the quality and character of the learners; after the establishment of mosque facilities, the students were familiar with prayer jamaah, read the Quran with Islamic poetry, could be da'i and daiyah islam, understanding hadith, tafsir alQur'an, able to write calligraphy and able to make scientific work of Islam. Changes that occurred after the Infrastructure materialized was the learners more religious, talented and disciplined.
\end{abstract}

Keywords: Infrastructure Facility, Character Education, Discipline, Talented, Religious

\section{PENDAHULUAN}

Penelitian ini dikaitkan dengan yang dapat berlangsung di sekolah dan penambahan Sarana dan Prasarana tekait lingkungan sekitar. Menurut Kristiawan (2015) dengan program pendidikan karakter, serta fungsinya dalam rangka meningkatkan karakter pada peserta didik, serta menanamkan nilai nilai karakter pada peserta didik. Yuliawan (2014) menyatakan dengan memanfatkan sarana prasarana siswa mampu menerima penjelasan guru dan lebih berminat mengikuti pelajaran. Dalam rangka meningkatkan kualitas pada lembaga pendidikan dalam persaingan global dalam hal positif dalam pendidikan serta membentuk karakter perserta didik perlu terus menerus adanya usaha dalam mencapai tujuan. Apsari dkk (2014) menyatakan bahwa dalam mencapai tujuan pendidikan diperlukan proses interaksi yang dilakukan di lingkungan belajar “for Indonesia, to make the learners' smart and have moral required mental effort revolution integrated with a comprehensive character education".

Diawali dari sering terjadinya hal-hal negatif yang terjadi karena pengaruh masyarakat seperti tindak kekerasan dan kenakalan remaja, menyangkut peristilahan yang dipakai Istilah pendidikan karakter baru muncul pada dekade terakhir di Amerika Serikat, termasuk yang dipakai di Indonesia dalam dua tahun terakhir ini. Pendidikan karakter sebagai "any deliberate ap proach by which school personnel,often in conjunction 
with parents and community members, help children and youth become caring, principled and respon sible". Maknanya kurang lebih pendidikan karakter merupakan berbagai usaha yang dilakukan oleh para personil sekolah, bahkan yang dilakukan bersama-sama dengan orangtua dan anggota masyarakat, untuk membantu anak-anak dan remaja agar menjadi atau memiliki sifat peduli, berpendirian, dan bertanggung jawab Menurut Novak, tak seorang pun yang memiliki semua kebajikan itu, arena setiap orang memiliki kelemahankelemahan. Seseorang dengan karakter terpuji dapat dibedakan dari yang lainnya (Lickona, 1991:50) Secara khusus tujuan pendidikan moral adalah membantu siswa agar secara moral lebih bertanggung jawab,menjadi warga negara yang lebih berdisiplin (McBrien \& Brandt, 1997).

Di Indonesia pernah dipakai istilah pendidikan budi pekerti dan pendidikan moral Pancasila. Sepanjang sejarahnya, di seluruh dunia ini, pendidikan pada hakikatnya memiliki dua tujuan,yaitu membantu manusia untuk menjadi cerdas dan pintar, dan membantu mereka menjadi manusia yang baik. Untuk menjadikan manusia yang cerdas dan pintar, boleh jadi mudah melakukannya, tetapi menjadikan manusia agar menjadi orang yang baik dan bijak, tampaknya jauh lebih sulit atau bahkan sangat sulit. Kilpatrick (1992) menyebutkan salah satu penyebab ketidak mampuan seseorang berlaku baik meskipun ia telah memiliki pengetahuan tentang kebaikan itu (moral knowing) adalah karena ia tidak terlatih untuk melakukan kebaikan (moral doing). Kevin Ryan dan Karen E. Bohlin (1999) Sekolah dituntut memainkan peran dan tanggung jawabnya untuk menanamkan dan mengembangkan nilai-nilai yang baik dan membantu para siswa membentuk dan membangun karakter mereka dengan nilai-nilai yang baik. Oleh sebab penguatan pendidikan karakter dalam konteks sekarang sangat relevan untuk mengatasi krisis moral yang sedang melanda di negara Indonesia (Santosa 2014:27).

Bagi Indonesia saat ini, karakter pendidikan juga berarti upaya sungguhsungguh, sistematis dan berkelanjutan membangunkan dan memperkuat kesadaran dan kepastian bahwa seluruh rakyat Indonesia tidak akan memiliki masa depan yang lebih baik tanpa membangun karakter orang Indonesia. Kristiwan (2015).

Oleh sebab itu, diperlukan suatu cara agar pendidikan dapat memperlihatkan tajinya dalam peran sertanya membenahi jatidiri bangsa (Asep Dahliyana 2017). Salah satu cara yang dilaksanakan dalam beberapa tahun ini 
yaitu dengan pengembangan pendidikan juga lingkungan di Desa Cintamanis juga

karakter.

Hal ini sesuai dengan penelitian oleh Alqurashi (2016) yang menjelaskan bahwa nilai efikasi diri yang tinggi di pengaruhi oleh faktor prestasi masalalu sehingga mempengaruhi hasil belajar pada saat sekarang. Dukungan Sarana Prasarana akan mempengaruhi hasil belajar sesuai dengan pendapat Torupere, Koroye (2016) yang mengungkapkan apa bila tidak adanya fasilitas yang mendukung maka akan menghambat pembelajaran sehingga hasil belajar siswa terpengaruhi.

Standar sarana prasarana menurut Permen diknas Nomor 24 tahun 2007 tentang"standar sarana prasaran sekolah/madrasah pendidikan umum mencakup perabot, peralatan pendidikan, media pendidikan, buku dan sumber belajar lainnya, teknologi informasi, lahan, bangunan, ruangruang dan instalasi daya dan jasa".

Menurut Sulastri dan Iklam Khalik (Guru YP Yaskami/Puspita) (Hasil Wawancara, 31 Oktober 2017) SMA Puspita Sebenarnya telah lama berdiri sebelum tahun 1999. Pada Tahun 1984-1996 Berdirinya SMP dan SMA Yayasan Yaskami dan tahun 1990 yang bernama "Yayasan Pendidikan Yaskami" saat itu kondisi sarananya hanya memiliki 4 Lokal saja dengan kondisi yang sederhana dan saat itu masih sepi dan akhirnya SMP dan SMA Yaskami tutup pada tahun 1996 dan Bangkit kembali Pada tahun 1999 Berubah nama menjadi "Yayasan Pendidikan Puspita".

Dibawah Kepemimpian Kepala Sekolah Siti Marsidah dari tahun 1999 sampai sekarang tahun 2017. Dalam hal ini kepala sekolah,bekerja sama dengan Yayasan Puspita dengan pendanaan dalam pembangunannya yang seluruh anggota Yayasan tersebut berhubungan dengan Lembaga Koprasi Yang Ada di Desa Cintamanis kecamatan Air Kumbang Yaitu Koprasi Himpunan Usaha Bersama (HUB) yang saat ini suatu koprasi yang merupakan Central terbesar Di Kecamatan Air Kumbang dan Telah Memiki aset Sebesar 18 Miliar Lebih (Hasil Wawancara dengan Anggota Koprasi HUB, Nyoman Suadnyani, 09 Oktober 2017).

Peran Yayasan, Kepala Sekolah dan masyarakat sangat berpengaruh dalam meningkatkan Sarana dan Prasarana sampai saat ini. Pada tahun 1999 Sampai dengan tahun 2000 Kondisi Sarana dan Prasarana di Yayasan SMA Puspita Belum banyak Perubahan hanya penambahan Lokal kelas 3 Lokal menjadi 7 Kelas dan kantor,kepala sekolah dan guru. Kemudian Pada Tahun 2008 Dengan Memamfaatkan Guru dan seluruh Siswa dan 
anggota Osis dalam pembuatan konblok dan batu batako dengan pemanfaat pelajaran Mutan lokal, terbuatlah ruangan-ruangan kecil seperti tempat sholat, ruangan komputer yang sekarang digunakan menjadi ruangan koprasi sekolah dan dan Ruangan praktik komputer TIK. Untuk lapangan Olah raga Voly, futsall yang masih beralaskan tanah. Kemudian pada tahun 2011 SMA Puspita Membangun Pagar Keliling Full 100 x 100 M, Gapura dan Pos Jaga sekuruti yang merupakan Usaha Yayasan Puspita. Kemudian pada Tahun 2013 SMA Puspita Mendapat Bantuan Dana Pembangunan Ruang kelas Baru (RKB) yang bersumber Pada Dana APBD Kabupaten Banyuasin dan telah membangun fasilitas Gedung sekolah 4 Lokal dan merobohkan gedung lama (4 Gedung Yayasan Yaskami) dan Membangun 4 gedung tersebut menjadi 4 Lokal yang baru dengan berstandar Nasional dan seluruhnya menjadi 7 Lokal Kelas dan 1 Lokal kelas Lama Menjadi Ruang Perpustakaan.dan Pada tahun 2014 telah membangun 2 Lokal Ruang kelas Baru Menyempurnakan lapangan Basket/Futsall, hasil Usaha Yayasan Puspita,komite dan Masyarakat kemudian Pada Tahun 2015 Telah Seluas 100 x 100 Meter Total Luas Sekolah Membangun lapangan Voli Putra dan Putri dan Seluas 1 Hektar (Hasil Observasi, 09 Oktober Membangun Lapangan Bulu tangkis. 2017).

Kemudian pada tahun 2016 telah Membangun

SMA Puspita di Kecamatan Air Ruang laboratorium dan Gudang seluas 18 x 7 Kumbang Saat ini Satu-satunya Lembaga

Meter dan terakhir pada saat ini tahun 2017 membangun 4 kantin dan Membangun Gedung Mushola seluas 7 × 7 Meter Beserta 2 WC Putra dan Putri dan tempat whudu dengan kerjasama dengan Komite dan Masyarakat dan telah Diresmikan Oleh Kepala UPTD Kecamatan Air Kumbang (Hasil wawan cara dengan Kepala SMA Puspita Siti Marsidah, 09 Oktober 2017)

Gambaran Spesifik dari Sarana yang ada di SMA Puspita Saat ini; 1) 9 Ruang Kelas; dan 1 Kelas Masih menumpang pada Ruang Laboratorium dan Kapasitas Seluruh Siswa Perkelas Tahun ajaran 2017/2018, Rata-Rata antara 32-36 Total 330 Siswa; 2) Ruang Laboratorium dan Gudang; 3) Ruang Guru dan 2 wc 4) Ruang Kantor TU; 4) Ruang Kepala Sekolah dan Wc; 5) Ruang Perpustakaan; 6) Ruang BK/UKS Masih Tergabung; 7) Ruang kecil Koprasi 8) Ruang Kecil Praktik Komputer (TIK); 9) 4 Kantin Sekolah 10) Tempat Parkir Guru; 11) 4 Wc Putra dan Putri dekat Kantin; 12) Gedung Mushola dan 2 Wc serta Tempat Whudu; 13) Post kecil Jaga Sekuriti; 14) Pagar Keliling full dan Gapura

.


Pendidikan Swasta yang Terkareditasi. A dan dengan benar (http:/smapus pita.sch.id). lembaga pendidikan yang berorientasi pada Kondisi sarana prasarana saat ini sebenarnya penguatan daya saing pada lembaga institusi masih jauh dibanding sekolah perkotaan. melalui sarana prasarana, khusunya di daerah Namun bila dibandingkan dengan sekolah lain kecamatan yang baru berkembang dan selalu Seperti SMKN 1 Air Kumbang,SMAN 1 Air berupaya mewujudkan manusia yang Kumbang, MA Al-Akbar, MA Nurul Hikmah berkarakter sesuai dengan nilai-nilai Pancasila. di Kecamatan Air Kumbang, Merupakan satuSMA Puspita Status Kepemilikan Yayasan,SK satunya lembaga Pendidikan Berakreditasi A Pendirian Sekolah; 10/YPP/SMU/CMB/VII/99, dan telah menerapkan program pembelajaran Tanggal SK Pendirian; 1999-07-01, SK Izin Berkarakter Kurikulum 2013, walaupun hanya Operasional; 417/ III.07/KP/2000, Tanggal SK Kelas X dan XI saja Namun Eksistensinya Izin Operasional; 2000-02-09, yang Beralamat Kesemuanya itu Berawal dari Penambahan di Jl. Inpres Dusun IV Cintamanis Baru KM XI sarana dan Prasarana Pendidikan.

Kec. Air Kumbang Kab.Banyuasin, RT/RW

Program yang diunggulkan di SMA 5/2, Dsn.1, Ds./Kel Cinta Manis Baru, Kec. Air Puspita Kecamatan Air Kumbang antara lain; Kumbang, Kab. Banyuasin, Prop.Sumatera 1) Menjadi Sekolah Yang Memiliki daya saing Selatan (Studi Dokumentsi pada dengan meningkatkan sarana dan prasarana; 2) http://www.Smapuspita.sch.id Hasil Observasi, mengembangkan sikap disiplin dan taat dengan 09 Oktober 2017).

hukum serta agama; 3) mengembangkan

Misi Sekolah SMA Puspita adalah Kemampuan keterampilan bidang Agama, Seni Unggul dalam Berilmu dan berteknologi, serta dan Olahraga; 4) mengembangkan potensi santun dalam beragama. Agar tercapainya Visi siswa melalui kegiatan ekstra kurikuler sesuai secara tepat maka Misi SMA PUSPITA Yaitu; dengan minat dan bakat; 5) mengembangkan 1) Meningkatkan Prestasi Akademik; 2) budaya Banyuasin; 6) mengembangkan Menciptakan lulusan yang siap melanjutkan penguasaan teknologi informasi dan 7) keperguruan tinggi dan siap terjun meningkatkan daya serap ke perguruan tinggi. kemasyarakat; 3) Meningkatkan prestasi Prestasi Setiap tahun SMA Puspita yang sering olahraga melalui kegiatan ekstrakulikuler dan didapat yang paling sering antaralain; Lomba sparing partner; 4) Meningkatkan ketakwaan LTBB bahkan pernah Menjadi Juara Lomba melalui pemahaman kehidupan beragama LTBB ditingkat Antar Kecamatan Lain Seperti 
di sekolah YKPP Pertamina Sungai gerong Sekolah Sunaryo Merupakan ketua PGRI di Kecamatan Maryana kabupatan Banyuasin. kecamatan Air Kumbang Yang saat ini Pernah juga pada Lomba Kaligrafi Mendapatan termotivasi untuk melanjutkan Pendidikannya Juara 1 pada Lomba yang diadakan di YKPP di Program Pasca Sarjana Jurusan Prodi Bahasa Pertamina Antar Kecamatan, prestasi lainnya Inggris di Universitas PGRI Palembang (Hasil yang paling sering yaitu dalam hal Lomba Obsevasi,09 Oktober 2017).

Gerak jalan, Lomba Olahraga Sepak Bola Dan

Program yang di Unggulkan di SMA Futsall, Lomba Voli Putra dan Putri. SMA Puspita Kecamatan Air Kumbang antara lain; Puspita aktif Mengikuti Kegiatan Perlombaan 1) Menjadi Sekolah Yang Memiliki daya saing Pada Kegiatan di tingkat kabupaten seperti dengan mening katkan sarana dan prasarana 2) Kegiatan O2SN dan pada kegiatan di tingkat Propinsi Sumatra Selatan di Kota Palembang yaitu kegiataan Kepramukaan walaupun hanya berpartisipasi namun hal tersebut merupakan suatu usaha dalam menembus kegiatan keaktifan dalam membentuk karakter melalui kegiatan diluar sekolah/ diluar kecamatan dan kabupaten. Baru baru ini SMA Puspita telah Menjadi tuan Rumah dalam Hal Kegiatan PKM yang di laksanakan Oleh Dosen Universitas PGRI Palembang, hal ini tentunya berpengaruh bagi Guru dalam mengembangkan pengetahuannya.

Melalui fasilitas sarana parasarana, SMA Puspita Sebelumnya Pernah Menjamu Prodi Program Pasca Sarjana Universitas PGRI mengembangkan sikap disiplin dan taat dengan hukum serta agama 3) mengembangkan Kemampuan keterampilan bidang Agama, seni dan olahraga; 4) mengembangkan potensi siswa melalui kegiatan ekstrakurikuler sesuai dengan minat dan bakat 5) mengembangkan budaya Banyuasin; 6) mengembangkan penguasaan teknologi informasi dan 7) meningkatkan daya serap keperguruan tinggi.

\section{Undang-undang No.20 Tahun 2003}

tentang Sisdiknas yang menyatakan bahwa tujuan Pendidikan adalah agar menjadi manusia yang beriman dan bertakwa kepada tuhan yang maha Esa, Berakhlak Mulia, sehat, berilmu cakap, kreatif, mandiri, dan menjadi Palembang dalam Bersosialisi Promosi Prodi Pasca Sarjana dan telah di hadiri oleh berbagai guru Sekolah Lain yang ada di sekitar warga negara yang demokratis serta bertang gungjawab. Oleh sebab penguatan pendidikan karakter dalam konteks sekarang sangat kecamatan. Dan kebetulan Wakil Kepala 
sedang melanda di negara Indonesia (Santosa 2014).

\section{METODE PENELITIAN}

Pada penelitian ini, metode yang digunakan adalah deskriptif kualitatif, yaitu suatu metode yang bertujuan menggambarkan bagaimana keadaan dan fenomena yang sebenarnya, kemudian dideskripsikan kedalam laporan penelitian. Metode kualitatif merupakan suatu proses penelitian yang dilakukan secara wajar dan natural sesuai dengan kondisi objektif di lapangan tanpa adanya manipulasi, serta jenis data yang di kumpulkan (Nana dan Sukmadinata 2012:140) Metode kualiatif yakni suatu penelitian yang di tujukan untuk mendeskripsikan dan menganalisis fenomena atau peristiwa. Dengan pendekatan penelitian deskriptif yaitu penelitian yang ditujukan untuk meng gambarkan fenomena-fenomena yang ada, yang berlangsung saat ini atau saat yang lampau (Nana dan Sukmadinata 2012:94). Alasan penulis memilih Pendekatan penelitian ini karena penulis bertujuan untu mendeskripsikan atau menggambarkan secara sistematis, aktual dan akurat mengenai permasalahan dalam penelitian ini. Sehingga penulis sendiri dapat lebih mudah dalam mengetahui gambaran dari objek penelitian.
Oleh sebab itu, penelitian yang dilakukan penulis yaitu dengan menggunakan pendekatan kualitatif. Sementara, metode penelitian ini juga menggunakan metode studi kasus (case study). Dengan menggunakan studi kasus ini peneliti berharap dapat mengidentifikasi pengembangan habituasi pendidikan karakter melalui kegiatan dengan perlengkapan sarana prasarana di SMA Puspita Air Kumbang. Sehingga dapat memberikan gambaran penguatan pendidikan karakter melalui Peningkatan Sarana Pras sarana. Lokasi penelitian ini adalah SMA Puspita Air Kumbang yang beralamat Jl. Inpres Dusun IV Cintamanis Baru KM XI Kec. Air Kumbang Kab. Banyuasin, RT/RW.5/2, Dsn. 1, Ds./Kel. Cintamanis Baru, Kec. Air Kumbang, Kab. Banyuasin, Propinsi Sumatera Selatan.

Sekolah tersebut merupakan satu-satunya sekolah yang telah Berkareditasi A di Kecamatan Air Kumbang. Adapun yang menjadi subjek dalam penelitian ini adalah warga sekolah yang ada di SMA Puspita. Subjeknya adalah sebagai berikut; (1) Kepala Sekolah, (2) Wakil Kepala Sekolah Bidang Kesiswaan, (3) Wakil Sarana Prasarana, (4) Tenaga Pengajar/Guru/PKn, (5) Staf Karyawan, (6) Komite Sekolah, dan (7) Siswa dan SMA Puspita dan selanjutnya dideskripsikan dalam bentuk laporan. 
Teknik pengumpulan data yang teknik wawancara dengan mengajukan digunakan dalam penelitian ini adalah teknik pertanyaan untuk memperoleh informasi yang observasi, wawancara mendalam, studi berkaitan dengan Prasarana berkarakter. dokumentasi dan studi literatur. dalam Studi dokumen sebagai data tambahan penelitian ini, pengolahan data dan analisis (sekunder) akan tetapi data ini berfungsi melalui proses menyusun, mengkategorikan memperjelas dan melengkapi data utama.Studi data, mencari kaitan isi dari berbagai data yang dokumen dilakukan dengan penelitian diperoleh dengan maksud untuk mendapatkan mengenai dokumen-dokumen yang berkaitan maknanya. Data yang diperoleh dan dengan Prasarana sebagai pembentuk karakter dikumpulkan dari responden melalui hasil di SMA Puspita di Kecamatan Air Kumbang. wawancara, observasi dan studi dokumentasi di Setiap teknik pengumpulan data, baik itu lapangan untuk selanjutnya dideskripsikan angket ,wawacara, observasi maupun dalam bentuk laporan.

dokumentasi, sama-sama mempunyai

Wawancara yang dilakukan dengan cara kekurangan dan kelebihan. Oleh karenanya mengadakan komunikasi langsung dengan untuk memperkecil kemungkinan ketidak pihak-pihak yang dapat mendukung akuratan dalam penelitian ini peneliti diperolehnya data yang berkaitan dengan menggunakan beberapa teknik sekaligus permasalahan yang diteliti guna memperoleh dengan harapan antara satu dengan yang data baik lisan ataupun tulisan atas sejumlah lainnya dapat saling melengkapi (Maman data yang diperlukan. Teknik wawancara untuk Abdurrahman dan Sambas Ali Muhidin mendapatkan data pelengkap berupa keadaan 2011:85) Dalam hal ini peneliti memadukan atau kondisi sosial, budaya dan kecendrungan hasil wawancara dengan dokumen yang ada di sekitar subjek, atau bahkan digunakan untuk dan mencari ketidaksesuaian antara hasil memperoleh jenis data primer seperti peneliti wawancara dengan dokumen. maksudkan di atas. Hal ini sangat penting untuk dijadikan bahan perbandingan dengan data yang diperoleh dengan taknik lain oleh peneliti. Atau dengan kata lain, sebagai bahan untuk mengadakan verifikasi (Arief Suryantoro dan FX. Suwarto 2007) Peneliti melakukan

\section{HASIL PENELITIAN DAN PEMBAHASAN}

Menurut Kepala Sekolah Siti Marsidah (hasil Wawancara, 11 Oktober 2017) kondisi sarana prasarana di SMA Puspita saat ini sebenarnya masih jauh bila dibandingkan 
Sekolah Perkotaan, namun sudah mulai ada hal mengelola kegiatan anggotanya dalam perubahan dan perkembangan mulai dari tahun kegiatan di sekolah dan luar sekolah tekait 1999-2017.Hal yang terjadi setelah di bakat. Untuk Ruangan Guru BK; Siswa telah adakannya parana Prasarana Hasil Penelitian dapat menyelesaikan pemasalahannya yang menyebutkan Perubahan yang terjadi setelah terkait dengan kedisiplinan. Fasilitas diadakanya Sarana dan Prasarana. Dalam hal selanjutnya yaitu lapangan olahraga seperti ini Peneliti hanya memba has hal yang terkait basket/ futsall, lapangan voly putra dan putri dalam pembentukan kualitas dan karakter pada dan lapangan bulutangkis, setelah diadakanya peserta didik dalam membentuk karakter siswa fasilitas tersebut; siswa menjadi aktif pada yaitu; Setelah berdirinya sarana Mushola dan lingkungan sekolah dan telah dapat kegiatan keagaman siswa telah terbiasa sholat menyalurkan minat dan bakat dan telah berjamaah, mampu bertilawah alquran dengan mengurangi kegiatan negatiflainya.

syair islami, mampu berdakwah dan menjadi Guru-guru di SMA Puspita terlibat dalam da'i dan daiyah, mengetahui tentang ilmu islam yang mendalam seperti ilmu fiqih, Hadist, dan tafsif Al-quran, mampu menulis kaligrafi dan evaluasi hasil belajar,dan mampu membuat karya tulis tentang islam. Untuk fasilitas Pagar Keliling dan sekuriti yang berhubungan dengan Kepolisian Air Kumbang; tingkat kedisiplinan meningkat dan tingkat kenakalan remaja menurun, terkait dengan kedisiplinan masuk dan keluarnya peserta didik pengembangan peserta didik untuk mengaktulaisasi berbagai potensi yang dimiliknya sehinga dengan demikian dapat berpengaruh dalam membentuk karaktersistik sesuai dengan kemampuan seorang guru harus memahami peserta didik secara mendalam pada lingkungan sekolah dan telah yang meliputi memahami peserta didik dengan menanggulangi berkeliarannya siswa di luar memanfaatkan prinsip-prinsip perkembangan lingkungan sekolah. Untuk Ruang kognitif, prinsip-prinsip kepribadian, dan Perpustakaan dan Ruang laboratorium; Siswa mengidetifikasi bekal ajar awal peserta didik, telah dapat mengembangkan keilmuannya dan Artinya Pendidik harus mampu memahami bakatnya dalam kegiatan proses pembelajaran. landasan pendidikan, menerapkan teori belajar setelah diadakannya Ruang Osis; Ketua Osis dan menentukan strategi pembelajaran telah dapat berlatih menjadi pemimpin dalam menentukan berdasarkan karakteristik peserta 
didik, kompetensi yang ingin dicapai, dalam gambar menghubungkan dengan karakter materi ajar, serta menyusun rancangan secara eksplisit, sistematis, dan berkesinam pembelajaran berdasarkan karakteristik peserta bungan dengan melibatkan aspek knowing the didik, kompetensi yang ingin dicapai dan good, loving the good, and acting the good materi ajar, serta menyusun rancangan (Hasil Wawancara degan Kepala Sekolah, 11 pembelajaran berdasarkan strategi yang dipilih. Oktober 2017).

Melaksanakan pembelajaran meliputi menata

Semua Guru di SMA Puspita sosok guru latar pembelajaran yang kondusif, merancang harus mampu menjadi panutan dan evaluasi pembelajaran yang meliputi rancangan melaksanakan profesi nya secara profesional dan melaksanakan evaluasi (assessment) proses sehingga ia bisa diandalkan. Berangkat dari dan hasil belajar secara berkesinambungan uraian di atas, maka jelaslah bahwa guru sangat dengan berbagai metode, menganalisis hasil berperanan dalam membentuk karakter bangsa evaluasi proses dan hasil belajar untuk yang memiliki jati diri dan bermartabat di menetukan tingkat ketuntasan belajar (mastery tengah-tengah bangsa lainnya. bila dikaitkan level) dan memanfaatkan hasil penilaian dengan sarana prasarana yaitu guru harus pembelajaran secara umum, mengembangkan mampu memiliki inisitaif dan kekreatifannya peserta didik untuk mengaktulaisasi berbagai walaupun tanpa sarana yang belum lengkap potensinya meliputi memfasilitasi peserta didik seperti memanfaatkan sumber daya pada untuk pengembangan berbagai potensi non lingkungan sekitar yang ada (Hasil Wawancara akademik (Hasil Wawancara dengan Kepala degan Kepala Sekolah, 11 Oktober 2017). Sekolah, 11 Oktober 2017).

Menurut Siti Marsidah (Kepala Sekolah)

Ha-hal lain yang dilakukan guru-guru di Sarana dan prasarana pendidikan di SMA SMA Puspita dalam Mengimplementasi Puspita di kecamatan Air Kumbang merupakan pembelajaran karakter adalah guru perlu salah satu sumber daya yang penting dan utama memperhatikan keunikan siswa masing-masing dalam menunjang kegiatan belajar mengajar di dalam menggunakan metode pembelajaran, sekolah, untuk itu perlu dilakukan peningkatan yaitu menerapkan dan pengembangan dalam pendayagunaan dan pengelolaannya, kurikulum sesuai lingkungan dengan agar tujuan yang diharapkan dapat tercapai. kelengkapan sarana yang ada atau Seiring dengan perubahan pola pemerintahan menyampaikan secara teoritis dengan media setelah di berlakukannya otonomi daerah, maka 
pola pendekatan manajemen sekolah saat ini prilaku moralnya melalui kegiatan-kegiatan berbeda pula dengan sebelumnya, yakni lebih keagamaan masing-masing seperti kegiatan di bernuansa otonomi. Untuk mengoptimalkan Mushola, gereja, dan pura; 7) disiplin dan penyediaan, pendayagunaan, perawatan dan pengelolaan kelas menjadi fokus dalam pengendalian sarana dan prasarana pendi dikan memecahkan masalah dan 8) pembelajaran pada setiap jenis dan jenjang pendidikan, yang berpusat pada karakteristik yang agamis (Hasil Wawancara dengan Kepala Sekolah, 11 dengan menghargai agama-agama lain di Oktober 2017). lingkungan sekitar di mana guru dan siswa

SMA Puspita di Kecamatan Air berkumpul untuk membangun kesatuan dengan kumbang meng implementasikan pembelajaran perbedaan agama yang dianut, dalan karakter adalah melalui Pemanfaatan sarana memecahkan masalah melalui kegiatan prasaran serta lingkungan masyarakat sekitar keagamaan masing-masing (Studi Dokumen yaitu dengan mengintegrasikan perkembangan Website Resmi SMA Puspita http://sma karakter ke dalam setiap aspek kehidupan di luar sekolah. 1) segala sesuatu di sekolah diatur puspita.sch. id, 25 Oktober 2017).

Sementara itu peran SMA Puspita di berdasarkan perkembangan hubungan antara Kecamatan Air kumbang dalam siswa, guru, dan masyarakat sekitar; 2) mengimplementasikan pembelajaran karakter lingkungan sekolah dan masyarakat sekitar dan melalui Sarana Prasarana mencakup keterkaitannya dengan kualitas karakterisik mengumpulkan guru, orang tua tokoh-tokoh peserta didik dimana ada ikatan yang jelas agama tokoh masyarakat dan siswa bersamayang menghubungkan siswa, guru, sekolah dan sama mengidentifikasi dan mendefinisikan masyarakat; 3) pembelajaran emosional dan unsur-unsur karakter yang mereka inginkan (2) sosial setara dengan pembelajaran akademik; memberikan pelatihan bagi guru tentang 4) kerjasama dan kolaborasi di antara sekolah bagaimana mengintegrasikan pembelajaran lain menjadi hal yang lebih utama karakter ke dalam kehidupan dan budaya dibandingkan persaingan; 5) nilai-nilai seperti sekolah, (3) menjalin kerja sama dengan orang keadilan, rasa hormat, dan kejujuran menjadi tua dan masyarakat agar siswa dapat bagian pembelajaran sehari-hari baik di dalam mendengar bahwa prilaku karakter itu penting maupun di luar kelas; 6) siswa-siswa diberikan untuk keberhasilan di sekolah dan di banyak kesempatan untuk mempraktekkan kehidupannya, dan (4) memberikan 
kesempatan kepada kepala sekolah, guru, orang tua tokoh agama masing-masing dan masyarakat sekitar untuk menjadi contoh prilaku sosial dan moral (Hasil Observasi di SMA Puspita, 24 Oktober 2017).

Menurut Siti Marsidah (Kepala Sekolah) Strategi yang dilakukan SMA Puspita di kecamatan Air Kumbang meningkatkan sarana dan prasarana dalam pembentukan karakter yaitu dengan Bekerja sama pada Dinas Pendidikan Kabupaten Banyuasin Bupati, Ang gota DPRD, Dinas UPTD dan Kepala Dinas Kecamatan Air Kumbang Setempat serta bantuan Wali murid, Komite Yayasan dan Tokoh Masyarakat. (Hasil Wawancara, 24 Oktober 2017)

Menurut Sunaryo (Wakil Kepala Sekolah) Strategi lainnya Yaitu Dalam hal Keterkaitan fungsi dari Sarana dan Prasarana dalam pembentukan karakter peserta didik yaitu Melalui prasarana dalam meningkatkan keaktifan dalam hal positif dan mengurangi kenakalan remaja, sehingga dapat membentuk karakteristik pribadi siswa Berdasarkan Potensi Masing-masing. Kesibukan dalam berbagai kegiatan merupakan suatu cara dalam mengurangi kenakalan remaja serta beliau juga merupakan ketua PGRI di meningkatkan keaktifan dan kekretifan siswa kecamatan Air Kumbang salah satu Motivasi dan guru sesuai dengan bidangnya masing- beliau yaitu beliau saat ini melanjutkan masing. Hal lain Melalui sarana prasarana Pendidikannya di Program Pasca Sarjana dalam membentuk sifat yang religius melalui kegiatan Rohis di Mushola. Untuk meningkatkan Budi pekerti luhur strategi bagi siswa yang kurang aktif melalui tugas yang diberikan dengan cara disibukan dengan berbagai kegiatan seperti berlatih menjadi pelayan masyarakat bila ada acara yang diadakan sekolah dan Luar sekolah ,dalam meningkatakan daya saing sekolah dalam hal ini berbagai kegiatan pertandingan seperti Olahraga, seni,dan lomba-lomba lainnya (Hasil Wawancara dengan Wakil Kepala Sekolah, 09 Oktober 2017)

Terutama pada kegiatan hari besar Seperti HUT RI, Hari besar PGRI, dan kegitankegiatan yang diadakan oleh Kepala Dinas Kecamatan SMA Puspita Selalu Menjadi Sarana dan Prasarana dalam hal kegiatan lingkungan Sekolah dan Masyarakat di kecamatan. SMA Puspita Selalu Menjadi Tuan Rumah dalam hal kegiatan Masyarakat, Karena SMA Puspita merupakan satu-satunya sekolah yang menjadi Central di Kecamatan Air Kumbang dan kebetulan Wakil Kepala Sekolah SMA Puspita Sunaryo, merupakan suami dari Kepala Sekolah SMA Puspita Siti Marsidah,$$
\text { kecamatan Air Kumbang salah satu Motivasi }
$$ 
Jurusan Prodi Bahasa Inggris di Universitas PGRI Palembang. Mereka berdua merupakan tokoh masyarakat yang paling berpengaruh besar di kecamatan Air kumbang termasuk dalam pemekaran Kecamatan Air Kumbang (Hasil Observasi di SMA Puspita, 24 Oktober 2017).

Dalam Hal memanfaatkan fasilitas sarana prasarana tentunya dengan menerapkan disiplin perawatan dalam segala kegiatan dengan melibatkan tenaga Pendidik dan Peserta didik dalam mengelolanya hal ini menjadi tanggung jawab bersama baik Wakil Sarana Prasarana, penjaga Sekolah Guru dan siswa. Dalam Membentuk karakter Religius Nonmus lim seperti Agama Kristen dan Hindu, selalu, Terutama Penilaian Pada Pendidikan Agama Kristen pada pendeta di gereja dan Guru di SMA Puspita di lingkungan sekitar. Untuk Agama Hindu melibatkan guru di SMA Puspita yang beragama Hindu, Kesemua nya itu termasuk dalam hal kegiatan Hari besar keagamaan dan penilaian Pendidikan Agama Pada Ujian sekolah. Menurut Siti Marsidah (Kepala Sekolah) (Hasil wawancara, 24 Oktober 2017).

Menurut Siti Marsidah (Kepala Sekolah) (Hasil wawancara, 24 Oktober 2017) Dalam mengoptimalkan pelaksanaan pembelajaran secara efektif dan mencegah kekosongan jam

pelajaran Peran Guru Piket sangat berpengaruh dalam mengaktifkan kegiatan proses belajar mengajar. Dalam kegiatan Ekstrakulikuler setiap peserta didik harus wajib dalam mengikuti salah satu kegiatan sesuai keinginan dan potensi yang dimilikinya. dalam menerapkan pelaksanaan evaluasi proses dan hasil belajar mengajar; mengopti malkan pelaksanaan program perbaikan dan pengayaan.Melalui program Guru BK berperan aktif dalam memotivasi dan membantu peserta didik dalam menyelesaikan permasalahan nya. Guru Bahasa Inggris dan Bahasa Indonesia membantu mengoptimalkan pembinaan dalam pembuatan karya tulis atau karya ilmiah/Mading dan lomba-lomba karya tulis di tingkat Propinsi dan kabupaten dan antar kecamatan. Dalam membantu memotivasi peserta didik, Kepala sekolah, Bendahara dan Wakil Kepala Sarana dan Prasarana, membantu memfasilitasi peserta didik untuk mengembangkan potensi dirinya melalui berbagai kegiatan perlombaan di sekolah maupun luar sekolah. dalam kegiatan mengoptimalkan pelaksanaan 9K SMA Puspita memberdayakan potensi yang ada di lingkungan sekolah dan untuk menumbuh kembangkan rasa ke pedulian sosial dan memberdayakan seluruh potensi yang ada 
dilingkungan sekolah untuk mewujudkan ke unggulan.

Melalui Sarana dan prasarana dalam kegiatan pembentukan karakter setiap peserta didik dapat berkembang secara optimal guna menghadapi persaingan dalam era globalisasi, dalam meningkatkan keunggulan di masyarakat. Termasuk juga Menerapkan manajemen mutu dengan melibatkan seluruh Warga Sekolah, Yayasan dan Masyarakat. Selain tanggung jawab Kepala sekolah dan Tanggung jawab Wakil Sarana Prasarana, juga merupakan tanggung jawab bersama (Hasil Wawancara dengan kepala sekolah,25 Oktober 2017)

Sekolah memiliki program ekstrakurikuler cinta tanahair, olahraga, dan seni dan Keagamaan masing-masing. Untuk kegiatan seni yang diajarkan adalah musik tradisional jawa dan sumatra yang bersumber dari daerah Banyuasin. Untuk Olahraga, hanya saat ini yaitu cabang olahraga Atletik,dan cabang Olahraga Basket, Fultsal, voly putra putri bulutangkis putra dan putri yang sarana prasarananya telah disediakan oleh sekolah. Selain itu juga ada ekstrakurikuler lainya seperti keagaaman, Kepramukaan dan LTBB (Hasil Wawancara dengan kepala sekolah, 25 Oktober 2017).
Dalam rangka menguatkan karakter religius Melalui sarana prasarana yaitu; pada kegiatan keagamaan di Mushola terdapat aktifitas latihan seperti; latihan berdakwah, latihan tilawah Quran dan kegiatan Rohislainnya pada setiap hari Sabtu pukul 15.00-17.35 Wib yang di bimbing oleh guru pembimbing Kemudian setiap waktu Ashar sholat berjamaah, dan selalu mengadakan perlombaan pada hari-hari besar Agama Islam. Jika Pada hari-hari besar Agama Islam seperti bulan Ramadhan tetap menghargai agama lain seperti Memberikan Ruang Kelas Khusus Kepada Agama Kristen dan Hindu yang dibimbing oleh guru masing-masing dan Melibatkan Penilaian Ujian Pendidikan Keagamaan Selain Islam Seperti Pada Kegiatan Ujian sekolah (Hasil Wawancara dengan Kepala Sekolah, 25 Oktober 2017).

Kemudian untuk menumbuh kembangkan karakter lainnya, melalui Latihan LTBB SMA Puspita Melibatkan Pelatih TNI dan Kepolisian di kecamatan Air Kumbang,dikarena SMA Puspita sering menjadi model dalam kegiatan upacara bendera di kecamatan Air Kumbang, dan mengadakan perlombaan LTBB di lingkungan sekolah dengan mengundang sekolah lain dengan Juri dari TNI dan Kepolisian di Kecamatan Air kumbang. Melalui Sarana dan prasana, SMA 
Puspita Merupakan Sekolah Yang Memfasilitasi Kegiatan-kegiatan lainnya Seperti Kegiatan Lomba Hari PGRI dan Lomba-lomba Kegiatan di Kecamatan yang di adakan Oleh Kepala UPTD Kecamtaan Air Kumbang dan Kepala Dinas Kecamatan Seperti Kegiatan HUT RI (Hasil Wawancara dengan Kepala Sekolah, 25 Oktober 2017).

Dalam rangka menumbuhkan karakter berbudi pekerti luhur sebagai pembentuk karakter dan tangung jawab dalam Pemilihan Ketua dan wakil OSIS Yang baru dengan melalui voting dan Promosi Langsung dengan Menyampaikan Visi dan Misi serta Program yang akan dilaksanakan di lingkungan sekolah hal ini dilakukan pada 2 Tahun setelah Kakak tingkat kelas XII Telah Naik Kelas, Pencalonan dilakukan Oleh Siswa Kelas X yang berprestasi dan memiliki dedikasi dan tanggung jawab serta kreatif. Sekolah memiliki KBM akademik dimulai pukul 12.15-17.35 WIB, sementara KBM Khusus di lakukan untuk mata pelajaran yang di UN-kan dan berlaku untuk anak kelas kelas 12 Mendekati UN. Sementara hari Senin Pukul 17.00-17.35 wib diadakan Upacara Penurunan Bendera. Dan pada hari sabtu pukul 15.00-17.35 Wib,dilakukan untuk kegiatankegiatan ekstrakurikuler (Hasil Wawancara dengan Kepala Sekolah, 25 Oktober 2017).
Fifi Punama Dewi, Notonegoro (2014) menyatakan bahwa pancasila adalah dasar falsafah negara Indonesia. Sehingga dapat diartikan bahwa pancasila merupakan dasar falsafah dan yang diharapkan menjadi pandangan hidup bangsa Indonesia, sebagai dasar pemersatu, lambang persatuan dan kesatuan ,serta bagian pertahanan bangsa dan negara.

Berdasarkan landasan filosofis tersebut, sehingga dapat diartikan bahwa pancasila merupakan dasar falsafah dan yang diharapkan menjadipan dangan hidup bangsa Indonesia, sebagai dasar pemersatu bangsa. sistem pendidikan nasional menem patkan peserta didik menjadi manusia yang bermoral, berbudi luhur, dan berakhlak mulia yang menjunjung tinggi dan memegang teguh norma-norma Agama saling menghargai perbedaan dalam menjalani kehidupan bermasyarakat dan bernegara. Menurut Adi Syahputra dkk (2017) beberapa paradigma pendidikan menyangkut peserta didik bahwa sesungguhnya dalam esensi yang paling fundamental karya sastra merepresentasikan berbagai nilai-nilai yang bisa dijadikan sebagai pandangan hidup. Berdasar kan landasan filosofis Pancasila, Undang-Undang Dasar 1945 dan Adi Syahputra dkk (2017) jelas bahwa peserta didik membutuhkan pendidikan karakter agar 
menjadi manusia yang saling hormat sebagai kekuatan dalam hidupnya (Nurul menghormati dengan perbedaan demi Zuhriah 2008).

terwujudnya bangsa yang bersatu "essential in Pendidikan karakter seharusnya menjadi a work of art is that it goes far beyond the pedoman utama didalam kegiatan lingkungan world of personal life: a writer speaks from the sekolah dan masyarakat sekitar bila dikaitkan spirit and heart as a human being to the spirit pada sarana prasarana dengan kegiatan and heart of humanity (Lynn Wilcox ekstrakulikuler sebagai pembentukan karakter. 2013:174). Terlebih menurut temuan Ahmad Dipertegas dengan pernyataan Karim (2013) dkk (2017) kesuksesan seseorang tidak yang menjelaskan bahwa, melalui ditentukan semata-mata oleh pengetahuan dan ekstrakurikuler siswa diarahkan memiliki kemampuan teknis (hard skill) saja, tetapi lebih karakter yang abadi dan universal seperti oleh kemampuan mengelola diri dan orang lain kejujuran, kedisiplinan, menghargai pluralisme, (soft skill). mempunyai empati dan simpati. Semua aspek

Nurul Zuhriyah (2008) mengatakan ini akan sangat menunjang kesuksesan siswa bahwa pendidikan karakter sama dengan kelak di masa mendatang. Sebab pada dasarnya pendidikan budi pekerti. Dimana tujuan budi kegiatan ekstrakurikuler ditujukan untuk pekerti adalah untuk mengembangkan watak mengetahui potensi dari setiap siswa baik itu atau tabi'at siswa dengan cara menghayati sebagai fungsi pengembangan, sosial, rekreatif, nilai-nilai keyakinan masyarakat sebagai maupun persiapan karir (Damanik 2014: 19). kekuatan moral hidupnya melalui kejujuran, Character.org 2017 “This year's winning dapat dipercaya, dan kerjasama yang practices include unique peer mediation menekankan ranah efektif (perasaan, sikap) programs, creative ways to integrate character tanpa meninggal kan ranah kognitif (berfikir and academic subjects, effective strategies for rasional) dan ranah psikomotorik (ketrampilan, developing student leadership and service terampil mengolah data, mengemukakan learning activities that build community within pendapat dan kerjasama). Seseorang dapat the school and beyond"(Character.org 2017). dikatakan berkarakter atau berwatak jika telah Nur Silay (2014:5) mengemukakan berhasil menyerap nilai dan keyakinan yang bahwa keduanya membahas berkaitan dengan dikehendaki masyarakat serta digunakan moral. Pendidikan karakter sebagai arus pendidikan komprehensif mencakup 
Pendidikan Kewarga negaraan (Howard 2014).

Dalam rangka menanam kan nilai-nilai karakter melalui buku ajar (Yaumi 2014:141) menyatakan bahwa strategi pengembangan buku ajar berbasis pendidikan karakter merupakan cara penyusunan dan pembuatan buku ajar dengan mengintegrasikan nilai-nilai karakter dalam buku ajar dan aktivitas pembelajaran. Dalam sosialisasi gerakan penguatan pendidikan karakter bahwa karakter sebagai poros pendidikan melalui program nawacita salah satunya dilakukan dengan membangun Pendidikan Kewarganegaraan, sejarah pembentukan bangsa, nilai-nilai patriotisme dan cinta tanah air, semangat bela negara, dan budi pekerti (Arie Budhiman 2017). Pada akhirnya dalam Membentuk karakteristik peserta didik disekolah, melalui sarana dan prasarana tentunya dapat Menanamkan sifat-sifat yang positif dan mengurangi kegiatan negatif, Keterkaitan fungsi dari Sarana dan Prasarana diatas tentunya dapat membentukan karakter peserta didik dalam meningkatkan keaktifan dalam mengembangkan potensi Peserta didik melalui berbagai kegiatan melalui fasilitas dilingkungan sekolah termasuk memberdayakan potensi yang ada di lingkungan sekolah.

\section{KESIMPULAN}

Perubahan yang terjadi setelah diadakanya Sarana dan Prasarana, terkait dalam pembentukan kualitas dan karakter pada peserta didik dalam membentuk karakter siswa yang Religius disiplin dan bakat; 1) Setelah berdirinya sarana Mushola dan kegiatan keagaman; siswa telah terbiasa sholat berjamaah, mampu bertilawah al-quran dengan syair islami, mampu berdakwah dan menjadi da'i dan daiyah, da mampu menulis kaligrafi dan mampu membuat karya tulis tentang islam; 2) fasilitas Pagar Keliling dan sekuriti yang berhubungan dengan Kepolisian Air Kumbang; Perubahan yang terjadi pada tingkat kedisiplinan meningkat dan tingkat kenakalan remaja menurun, terkait dengan kedisiplinan masuk dan keluarnya peserta didik pada lingkungan sekolah dan telah menanggulangi berkeliarannya siswa di luar lingkungan luar sekolah; di lingkungan dan luar sekolah; 3) Ruang perpustakaan dan Ruang laboratorium dalam hal ini Siswa telah dapat mengembangkan keilmuannya dan bakatnya dengan kegiatan pembelajaran; 4) Ruang Osis dalam hal ini ketua Osis telah dapat berlatih menjadi pemimpin dalam hal mengelola kegiatan anggotanya dan dalam kegiatan; 5) Guru BK, hal yang terjadi setelah diadakan fasilitas tersebut, Siswa telah dapat 
menyelesaikan permasalahannya terkait dengan kedisplinan siswa di sekolah; 6) lapangan olahraga basket/futsall, lapangan voly putra dan putri dan lapangan bulu tangkis; setelah diadakanya fasilitas tersebut siswa menjadi aktif pada lingkungan sekolah dan telah dapat menyalurkan minat dan bakat dan telah mengurangi kegiatan negatif lainya.

\section{DAFTAR PUSTAKA}

Adi Syahputra dkk. (2017). Paradigma Pendidikan Karakter Melalui Pembelajaran Bahasa Dan Sastra Indonesia Di Era Global. FKIP Universitas HKBP Nommensen Pematang siantar dalam: Seminar Nasional Pascasarjana di Universitas Negeri Malang Jember.

Ahmad, S., Kristiawan, M., Tobari, T., \& Suhono, S. (2017). Desain Pembelajaran SMA Plus Negeri 2 Banyuasin III Berbasis Karakter Di Era Masyarakat Ekonomi ASEAN. Iqra (Educational Journal), 2(2), 403-432.

Alqurashy, E. (2016). Self Effycacy In Online Learning Environmets: A Literaure Review,(Online). Journal Education Research, Vol.9 No.1.

Arief Suryantoro dan FX Suwarto. (2007). Penelitian, Metode Sosial \& Teknik. In P. S. UNIVERSAL, Skripsi.Nur Indah Fadhilah (p. 97). Yogyakarta: (Yogyakarta: ANDI 2007).

Aspari dkk (2014). Pengaruh,Efikasi Diri, Pemanfaatan gaya belajar,dan lingkungan Teman Sebaya Terhadap Prestasi Belajar
Akutansi. Studi Kasus di SMK Negeri 1 Surakarta.

Budhiman, Arie (2017). Gerakan Penguatan Pendidikan Karakter. Jakarta: Kemendikbud.

Character.org. (2017 ). at the National Forum on Character Education . in Arlington: Character.org will honor.

Dahliana, A. (2017). Penguatan Karakter Melalui kegiatan. Jurnal Sosologi, Vol. 5 No.1

Damanik, S. (2014). Pramuka Ekstrakurikuler Wajib Di Sekolah. Jurnal Ilmu Keolahragaan 13 (2). 16-21.

Dwijayanty, R., \& Elfira, C. (2017). Kementrian Pendidikan Republik Indonesia. 2015. Permendikbud Nomor 24 Tahun 2007 Tentang Standar Sarana dan Prasarana di Fakultas Ekonomi Di Universitas Negeri Surabaya. Jurnal Dosen dan Mahasiswa S1 Pendidikan Tata Niaga (JPTN) Pengaruh Efikasi diri dan Sarana Prasarana tehadap hasil belajar siswa Pada Mata Pelajaran Administrasi Transaksi Kelas XII Pemasaran SMK Negeri 4 Surabaya. Vol. 1 No.2.

Fifi Purnama Dewi. (2017:2). Buku PKn. diponegoro No.76A: Penerbit : Citra Pustaka.

Howard, R. W., et al. (2014). Politics of character education. Educational policy (18) 188-215.

Kristiawan, M. (2016). Telaah Revolusi Mental dan Pendidikan Karakter Dalam Pembentukkan Sumber Daya Manusia Indonesia yang Pandai dan Berakhlak Mulia. Ta'dib, 18(1), 13-25. 
Kristiawan, M. (2015). A Model of Educational Character in High School Al-Istiqamah Simpang Empat, West Pasaman, West Sumatera. Research Journal Education, 1(2), 15-20.

Karim. (2013). Pengaruh Keikutsertaan Siswa dalam Bimbingan Belajar dan Ekstrakurikuler terhadap Prestasi Belajar Metematika. Jurnal JMP IAIN Antasari.

Kilpatrick, W. (1992). Moral Illiteracy. Chapter 6 in Why Jhonny Can't Tell Right from Wrong and What We Can Do About It.Edited by J.H Clarke. New York: A Touchstone Book.

Koroye, T. (2016). The Influence Of School Physical Environment On Secondary School Student Academic Performace In Bayelsa State,. Asian Journal of Education Research, Vol.4 No. 2.

Lickona, T. (1991). Educating for Character: How Our School Can Teach Respect and Responbility. New York: Bantam Book.

Lynn, W. (2013). Psikologi Kepribadian: Analisis Seluk-beluk Kepribadian Manusia. Jogjakarta: IRCiSoD.

Maman Abdurrahman dan Sambas Ali Muhidin. (2011:85). Panduan Praktis Memahami Penelitian. Bandung: CV. Pustaka Setia.

Mc Brien, J. B. (1999). The Languange of Learning: A Guide To Education Terms: Alexandria, VA: Association for Supervision and Curriculum Development. New York: "Make You School A School of Character". Character Mattew.www.Cortland.edu/Character.

Nana \& Sukmadinata. (2012). Metode
Penelitian Pendidikan. Bandung: PT Remaja Rosdakarya.

of Nurul Zuhriah. (2008). Pendidikan Moral dan Budi Pekerti. Jakarta: PT Bumi Aksara.

Ryan, K. d. (1999). Buillding Character in Schools: Pactical Ways to Bring Moral Instruction to Life. San Francisco: JOSSEY-BASS A Wiley Imprint.

Santosa, A. (2014). Implementasi Pendidikan Karakter Dalam Membangun Kemandirian dan Disiplin Siswa di MTsN Kanigoro kras Kabupaten Kediri. Jurnal Didaktika Religia , 2 (1) 21-38.

Silay, Nur. (2014). Another type of character education : citizenship Education. Internationa Journal of Education, (6) 110.

Undang- undang No.20 Tahun 2003 Tentang Sistem Pendidikan National. Sistem pendidikan Nasional. Jakarta: CV Tamita Utama.

Williams \& Scnaps, E. (1999). Character Education:The foundation for techer Education. Washington DC: Character Education Partnership

Yaumi (2014). Pendidikan karakter landasan, pilar \& implementasi. Jakarta: Prenadamedia Group

Yuliawan, A. (2014). Pengaruh Sarana dan Prasarana Belajar Sekolah Terhadap Motivasi Beajar Siswa di SD Muhammadiyah 1 Program Khusus Wonogiri Tahun Ajaran 2013/2014. Universitas Muhammadiyah Surakarta. 
JMKSP

Jurnal Manajemen, Kepemimpinan, dan Supervisi

Volume 2, No. 2, Juli-Desember 2017 Pendidikan 